\title{
JOURNAL.RU
}

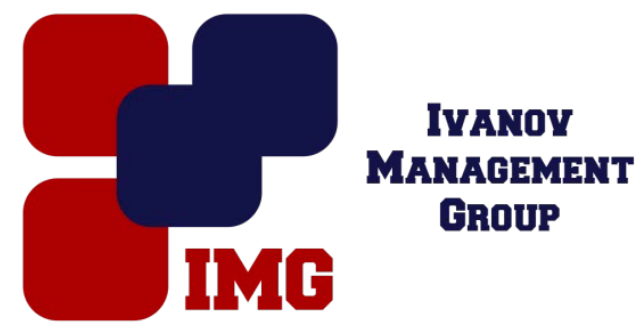

Никитина А.А, Васина Н.И

Омский государственный аграрный университет

Омск, Россия

doi: 10.18411/lj-30-04-2017-2-11

idsp 000001:lj-30-04-2017-2-11

\section{Оценка качества маркировки и упаковки твороженных изделий для детского питания на соответствие с ГОСТ 30625-98}

\section{Аннотация}

Незаменимым и обязательным продуктом детского питания является молоко. Среди продуктов животного происхождения оно занимает значительное место. Для того, чтобы детский организм работал без сбоев, его нужно обеспечить всем необходимым. Одним из первых продуктов, которые включают в питание ребенка с раннего возраста, является творожок для детского питания.

Ключевые слова Творог, здоровое питание, маркировка, ассортимент, детский организм.

Главным преимуществом детского творожка является помощь в улучшении пищеварения за счет питательных веществ: фосфора, кальция, калия, фтора, хлор, натрий, магний, железо и многие другие, содержащихся в данном продукте. При выборе любой продукции, а особенно продуктов детского, в первую очередь следует обратить внимание на информацию нанесенную на упаковку в качестве маркировки. Информация, которая должна быть отражена на этикетке творожков для детского питания в соответствии с ГОСТ 30625-98 «Продукты молочные жидкие и пастообразные для детского питания. Общие технические условия».

Для исследования были взяты два образца: 


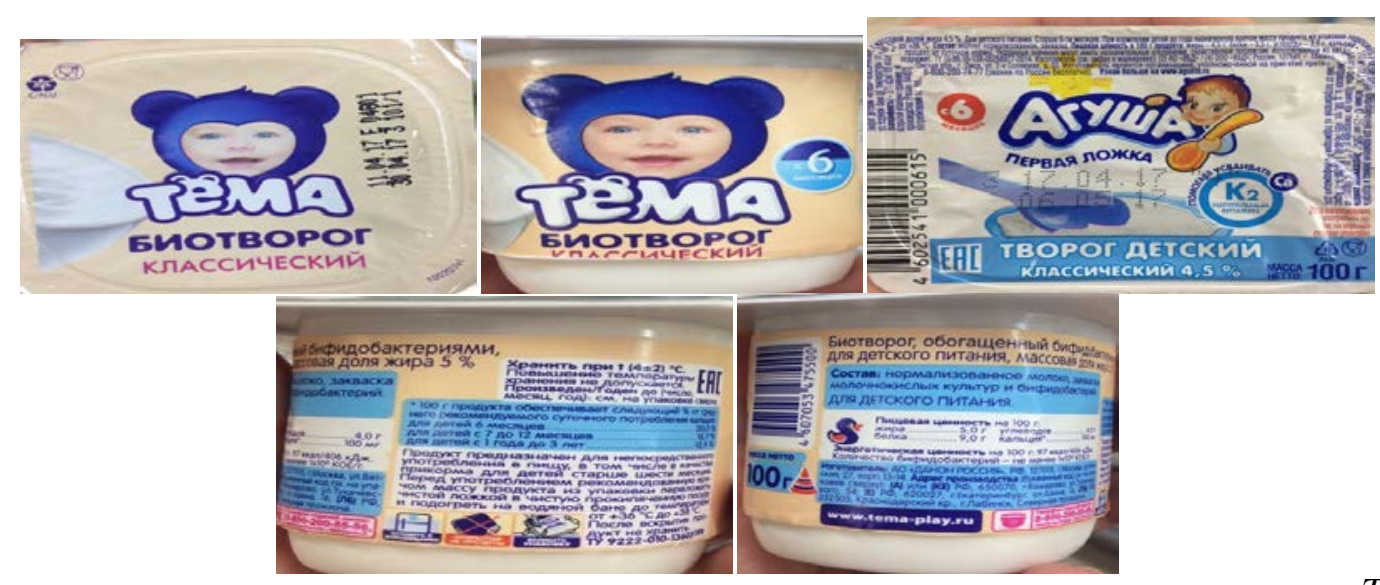

Таблийа 1.

Сравнительная оченка исследуемых образиов на соответствие с ГОСТЗ062- 98

\begin{tabular}{|c|c|c|}
\hline Требования к упаковке по ГОСТ 30625 - 98 & Образец 1 & Образец 2 \\
\hline Наименование предприятия - изготовителя & + & + \\
\hline Адрес и товарный знак для предприятий, его имеющих; & + & + \\
\hline Наименование продукции и/или вида & + & + \\
\hline Масса нетто и объем & + & + \\
\hline Состав продукта & + & + \\
\hline Обозначение нормативного документа на продукцию & + & + \\
\hline Срок годности & + & + \\
\hline Условия хранения до и после вскрытия & + & + \\
\hline Пищевая и энергетическая ценность & + & + \\
\hline Содержание витаминов и минеральных веществ & + & + \\
\hline Рекомендации по использованию & + & + \\
\hline Информация о сертификации & + & + \\
\hline Дополнительная информация & + & + \\
\hline
\end{tabular}

Изучив упаковку данных образцов и сделав сравнение на соответствие с ГОСТ 30625 - 98 «Продукты молочные жидкие и пастообразные для детского питания. Общие технические условия», можно сделать вывод, что все данные содержащиеся на упаковке исследуемых образцов творожков для детского питания полностью соответствуют требованиям ГОСТ 30625 - 98. Исходя из вышесказанного, можно смело говорить о том, что производитель строго соблюдает все правила изготовления своей продукции, а это значит, что вполне можно доверять и покупать данные продукты для своего чада.

\section{$* * *$}

1. $\quad$ ГОСТ 32927 - 2014. Творог для детского питания. Технические условия - Введ. 201601-01.-М.: Изд-во стандартов, 2015.- 8 с.

2. Никитина, А. А. Обезжиренное молоко - польза или вред?/ А.А.Никитина, А. В. Мощенко // Научный альманах- 2016.- С. 295 - 297.Шмат Е.В., Заболотных М.В., Корниенко Е.В. Электронное учебное пособие «Производственный ветеринарносанитарный контроль»/ Шмат Е.В., Заболотных М.В., Корниенко Е.В. - Хроники объединенного фонда электронных ресурсов Наука и образование, 2015.- С.71. 